Article

\title{
Combined Effect of Activated Carbon Particles and Non-Adsorptive Spherical Beads as Fluidized Media on Fouling, Organic Removal and Microbial Communities in Anaerobic Membrane Bioreactor
}

\author{
Daeeun Kwon ${ }^{1}$, Theo Y.C. Lam ${ }^{2,3}{ }^{(0)}$, Minseok Kim ${ }^{1}$, Giin-Yu Amy Tan ${ }^{2}$, Po-Heng Lee ${ }^{3}$ and Jeonghwan Kim ${ }^{1, *}$ \\ 1 Department of Environmental Engineering, Program in Environmental and Polymer Engineering, Inha \\ University, Inharo 100, Michuholgu, Incheon 22212, Korea; kwonde15@gmail.com (D.K.); \\ asmm1207@naver.com (M.K.) \\ 2 Department of Civil Engineering, The University of Hong Kong, Pokfulam, Hong Kong; \\ yctheolam@gmail.com (T.Y.C.L.); gyatan@hku.hk (G.-Y.A.T.) \\ 3 Department of Civil and Environmental Engineering, Imperial College London, London SW7 2AZ, UK; \\ po-heng.lee@imperial.ac.uk \\ * Correspondence: jeonghwankim@inha.ac.kr; Tel.: +82-32-860-7502; Fax: +82-32-865-1425
}

\section{check for}

updates

Citation: Kwon, D.; Lam, T.Y.C.; Kim, M.; Tan, G.-Y.A.; Lee, P.-H.; Kim, J. Combined Effect of Activated Carbon Particles and

Non-Adsorptive Spherical Beads as Fluidized Media on Fouling, Organic Removal and Microbial Communities in Anaerobic Membrane Bioreactor. Membranes 2021, 11, 365. https:/ / doi.org/10.3390/membranes11050365

Academic Editor: Anja Drews

Received: 28 April 2021

Accepted: 13 May 2021

Published: 18 May 2021

Publisher's Note: MDPI stays neutral with regard to jurisdictional claims in published maps and institutional affiliations.

Copyright: (c) 2021 by the authors. Licensee MDPI, Basel, Switzerland. This article is an open access article distributed under the terms and conditions of the Creative Commons Attribution (CC BY) license (https:/ / creativecommons.org/licenses/by/ $4.0 /)$.

\begin{abstract}
The combined effect of acrylonitrile butadiene styrene (ABS) spherical beads and granular activated carbon (GAC) particles as fluidized media on the performance of anaerobic fluidized bed membrane bioreactor (AFMBR) was investigated. GAC particles and ABS beads were fluidized together in a single AFMBR to investigate membrane fouling and organic removal efficiency as well as energy consumption. The density difference between these two similarly sized media caused the stratified bed layer where ABS beads are fluidized above the GAC along the membrane. Membrane relaxation was effective to reduce the fouling and trans-membrane pressure (TMP) below 0.25 bar could be achieved at $6 \mathrm{~h}$ of hydraulic retention time (HRT). More than $90 \%$ of soluble chemical oxygen demand (SCOD) was removed after $80 \mathrm{~d}$ operation. Biogas consisting of $65 \%$ of methane was produced by AFMBR, suggesting that combined use of GAC and ABS beads did not have any adverse effect on methane production during the operational period. Scanning Electron Microscope (SEM) examinations showed the adherence of microbes to both media. However, 16S rRNA results revealed that fewer microbes attached to ABS beads than GAC. There were also compositional differences between the ABS and GAC microbial communities. The abundance of the syntrophs and exoelectrogens population on ABS beads was relatively low compared to that of GAC. Our result implied that syntrophic synergy and possible occurrence of direct interspecies electron transfer (DIET) might be facilitated in AFMBR by GAC, while traditional methanogenic pathways were dominant in ABS beads. The electrical energy required was $0.02 \mathrm{kWh} / \mathrm{m}^{3}$, and it was only about $13 \%$ of that produced by AFMBR.
\end{abstract}

Keywords: anaerobic fluidized bed bioreactor; GAC; ABS media; energy reduction

\section{Introduction}

Media fluidization is one of the key aspects to determine the performance of AFMBR in the treatment of low strength wastewater such as domestic sewage [1-3]. The media materials fluidized by bulk recirculation alone through AFMBR provides a surface area for cell growth [4-13]. While AFMBR is widely applied in wastewater treatment along with the production of renewable energy in the form of methane, membrane fouling results in the loss of performance of a membrane due to the deposition of rejected wastewater constituents. GAC particles in AFMBR are often used to provide mechanical cleaning along the membrane surface to reduce membrane fouling [6,14].

While GAC particles can be an excellent tool as fluidizing media [15-17], the particles can be broken very easily by frequent collisions due to their weak rigidity during long-term 
reactor operation. This phenomenon should be more pronounced with larger media size, a higher recirculation rate or mixing intensity through the AFMBR reactor [18]. As a result, GAC particles that are ground into a smaller size can accelerate the membrane fouling because the particles should be deposited on membrane surface or even within membrane pores due to the formation of very dense cake layers easily [18-21]. Fluidizing the media accounts for the major portion of the energy in the operation of AFMBR, but it can depend strongly upon their intrinsic properties [5,22,23]. For example, higher specific gravity of the media such as GAC than the bulk wastewater present in the reactor, which is often higher than 2.0, requires more energy needed for the media fluidization than smaller ones. Given that the packing ratio of GAC particles is lower, recirculation flowrate through the reactor will be reduced, and thus less GAC particles are expected to be abrased during media fluidization. Nevertheless, membrane fouling is still severe if the upward flowrate is not enough for the GAC particles to cover the whole surface area of the membrane.

Significant efforts were made to apply various scouring agents such as zeolite $[8,12,13]$ and plastic agent [24-26] alternatives to the GAC in AFMBR, but only the usage of single media has been considered. Moreover, the use of inorganic particles is still of concern for practical applications because the particles are most likely abrasive in suspension to the membrane. The ABS is a cost-effective, polystyrene-based polymer composite material that has been used widely for various industrial applications [27-29]. The advantage of ABS can hold excellent mechanical stability and chemical resistance. The ABS-based materials should employ a low deformation rate. As a result, they can maintain intrinsic properties suitable for long-term reactor operation, even under harsh environmental conditions [30]. Additionally, the ABS beads have lower specific gravity than the GAC, thus requiring low energy consumption for their fluidization. However, the smooth surface of ABS beads provides less surface area for the growth of biofilm than that by GAC [31-33]. The AFMBR was operated using plastic beads as single fluidized media for domestic wastewater treatment application [24]. It was reported that bulk volatile suspended solid (VSS) concentration was about 4-5 times higher than those reported with the AFMBR system using the GAC, where most active microorganisms can be grown.

The objective of this study was to combine the GAC particles and ABS beads having the different specific gravity and surface properties as fluidized media while having similar sizes to investigate whether their combined usage is complementary and their microbial communities on each media are similar in the AFMBR treating low-strength wastewater. Specifically, this study examined whether combining ABS beads with GAC could have a synergistic impact on the AFMBR performances such as fouling control, organic removal efficiency and methane production. Although the characteristics of GAC as a biocarrier has been widely researched [34], little is known about the capacity of ABS media to act as a biocarrier and fouling mitigation in the presence of GAC with the AFMBR system. Previous studies have primarily focused on the elimination of biofilm on ABS instead of biofilm development, as ABS is commonly used in medical devices [35-37]. Thus, we considered that there is a need to study whether ABS can support methane production from a microbial perspective. In addition, the use of plastic beads was applied to reduce the membrane fouling in the membrane bioreactor, but only single media has been used as a scouring agent to clean the membrane $[38,39]$. Key questions, such as whether ABS beads could harbor the appropriate microbial community for methane production and whether biocarrier materials would also influence such community formation, hold important implications for reactor performance. Therefore, it is necessary to investigate the impact of using combined usage of media on microbial compositions and energy requirements, as well as reactor performance, which is the key to successful AFMBR operation under the dual media fluidization. 


\section{Materials and Methods}

\subsection{AFMBR Operation}

A laboratory-scaled AFMBR system was developed as shown in Figure 1 and applied in this study. The reactor was made using acrylic materials with a total reactor volume of $4 \mathrm{~L}$. A flat-tubular ceramic membrane consisting of alumina dioxide with a pore size of $0.5 \mathrm{um}$ and an effective area of $0.1 \mathrm{~m}^{2}$ was applied. The membrane was submerged into the AFMBR and operated by a peristaltic pump (Green Tech, GT-150d, Suwon-si, Korea) at constant permeate flux. A sedimentation tank was installed at the upper part of the membrane reactor to prevent the fluidized media from entering into the recirculation pump (PAN WORLD, NH-150S, Ibaraki-ken, Japan). A recirculation pump was installed at the bottom of the reactor for recirculating bulk suspension from the top of the settling tank to the bottom of the membrane reactor to allow both media to be fluidized along the membrane surface at $3 \mathrm{~L} / \mathrm{min}(0.028 \mathrm{~m} / \mathrm{s})$. Synthetic feed wastewater was prepared by using sodium acetate and sodium propionate with $300 \mathrm{mg} / \mathrm{L}$ of chemical oxygen demand (COD). The $30 \mathrm{mg} / \mathrm{L}$ of ammonium nitrogen and $1 \mathrm{mg} / \mathrm{L}$ of phosphate was prepared by using ammonium chloride and potassium phosphate, respectively. Sodium bicarbonate with $100 \mathrm{mg} / \mathrm{L}$ was injected into a feed solution to maintain a neutral $\mathrm{pH}$. A level sensor was installed to maintain the water level in the reactor by controlling the feed pump. The reactor was seeded by adding $200 \mathrm{~mL}$ of biomass, which is taken from the anaerobic digester operated at the local sewage treatment plant. A Supernatant was added with a $100 \mathrm{~mL}$ volume of $1 \% v / v$ into a feed tank to provide trace nutrients for the growth of microorganisms. A Tedlar bag was installed at the top of the reactor to collect biogas produced by AFMBR operated at room temperature.

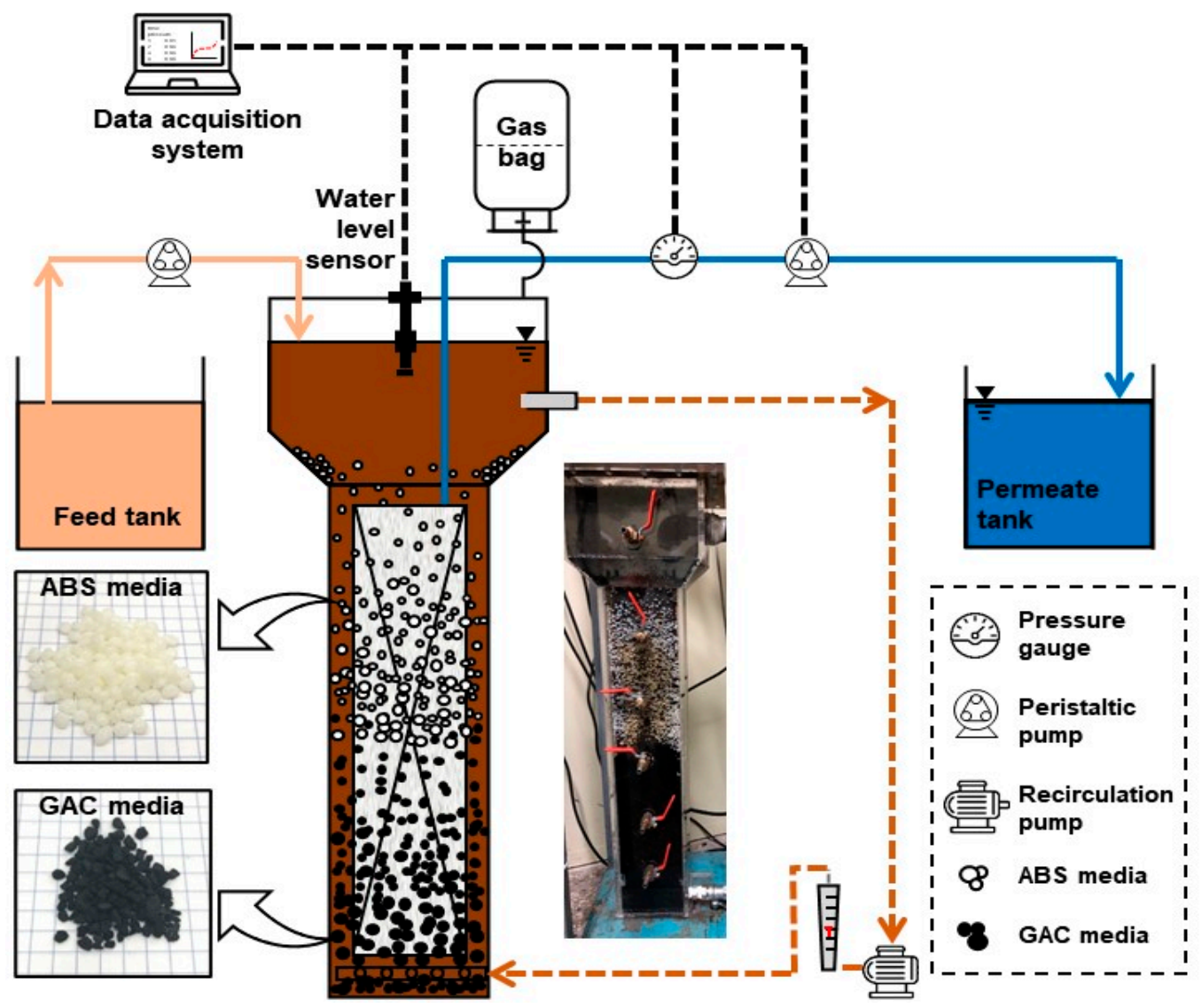

Figure 1. Schematic diagram of AFMBR with the dual media process. 


\subsection{Selection of Fluidized Media}

In this study, two types of media of GAC particles (Calgon Carbon, FILTRASORB 300, Altoona, PA, USA) and ABS plastic beads (Terluran, GP-35, Frankfurt am Main, Germany) were applied as fluidized media in AFMBR. Table 1 shows the characteristics of each media used in this study. The specific gravity of GAC particles and ABS plastic spherical beads was about 2.0 and 1.04, respectively. The size of ABS beads and GAC was about 2.5 and $1.5 \mathrm{~mm}$ on average, respectively. Each media was added at $25 \%$ of packing ratio into the AFMBR reactor. Since the ABS plastic beads have a lower specific gravity, ABS could be fluidized above the GAC particles at a constant bulk recirculation rate. In other words, the bottom and the top half of the membrane area was covered by GAC particles and ABS spherical beads fluidized, respectively, as demonstrated in Figure 1.

Table 1. Characteristics of fluidized media.

\begin{tabular}{lcc}
\hline & ABS Plastic Beads & GAC Particles \\
\hline Specific gravity & 1.04 & 2.00 \\
Diameter $(\mathrm{mm})$ & $2 \sim 3$ & $1 \sim 2(>0.84)$ \\
Surface area $\left(\mathrm{m}^{2} / \mathrm{g}\right)$ & 0.28 & $700 \sim 1300$ \\
Moisture absorption $(\%)$ & 0.95 & 2.00 \\
Shape & Flat-sphere & Angular-sphere \\
\hline
\end{tabular}

\subsection{Operation of AFMBR}

Table 2 summarizes the operational conditions of the AFMBR during $180 \mathrm{~d}$ reactor operation. Operational periods were classified into three phases, where different HRTs were applied. The recirculation flow rate was fixed at $3 \mathrm{~L} / \mathrm{min}$ to avoid the overflow of ABS plastic beads from the reactor. In Phase I, the HRT was maintained at $8 \mathrm{~h}$ during the initial three months of operation, which corresponded to $5.3 \mathrm{~L} /\left(\mathrm{m}^{2} \mathrm{~h}\right)$ of set-point flux. In Phase 2, the HRT was reduced to $6 \mathrm{~h}$ by increasing the permeate flux to $7.1 \mathrm{~L} /\left(\mathrm{m}^{2} \mathrm{~h}\right)$. After $20 \mathrm{~d}$ reactor operation in Phase 2, the operational mode of the membrane was changed by activating 1 min membrane relaxation every $9 \mathrm{~min}$ membrane filtration for $70 \mathrm{~d}$ (Phase 3). Membrane relaxation was performed by maintaining the media fluidization along the surface of the membrane without producing treated effluent (permeate).

Table 2. Operational conditions of AFMBR

\begin{tabular}{lccc}
\hline \multicolumn{1}{c}{ Period } & $\mathbf{1}$ & $\mathbf{2}$ & $\mathbf{3}$ \\
\hline Day & $0 \sim 90$ & $91 \sim 110$ & $111 \sim 180$ \\
Flux $\left(\mathrm{L} / \mathrm{m}^{2} \mathrm{~h}\right)$ & 5.3 & 7.1 & 7.1 \\
HRT $(\mathrm{h})$ & 8 & 6 & 6 \\
Relaxation & & & Filtration 9 min \\
Recirculation rate & 3 & 3 & Relaxation 1 min \\
$(\mathrm{L} / \mathrm{min})$ & 25 & 25 & 3 \\
Temperature $\left({ }^{\circ} \mathrm{C}\right)$ & & & 25 \\
\hline
\end{tabular}

\subsection{Microorganism Analysis}

Samples of bulk suspended liquid, GAC and ABS media were collected on day 168 during the steady-state condition, which is near the end of the operation. Samples were preserved with ethanol and stored at $-20{ }^{\circ} \mathrm{C}$ prior to DNA extraction. DNA extraction was performed using PowerSoil DNA Isolation Kit (Qiagen, Venlo, Netherlands). $16 \mathrm{~S}$ rRNA gene sequencing was performed using Illumina HiSeq with universal primer sets 515F (5'-GTGCCAGCMGCCGCGGTAA-3') \& 909R (5'-CCCCGYCAATTCMTTTRAGT$\left.3^{\prime}\right)$ for bacterial amplification and 519F (5'-CAGCMGCCGCGGTAA- $\left.3^{\prime}\right)$ and 806R (5'GGACTACVSGGGTATCTAAT- $3^{\prime}$ ) for archaeal amplification. Paired-end raw sequences were processed using QIIME 2 v2020.6 [40]. High-quality sequences with a minimum 
quality score of 30 were obtained using DADA2 pipeline [41] for denoising. Taxonomic classification was performed using pre-fitted sklearn-based taxonomy classifier [42] with a SILVA 138 Ref NR database [43]. Visualization of the microbial composition was done using Phyloseq [44]. Shannon index was selected to evaluate the alpha diversity. Principal Coordinate Analysis ( $\mathrm{PCoA}$ ) was selected to evaluate the beta diversity using unweighted UniFrac distance metrics.

\subsection{Analytical Methods}

In this study, SCOD and volatile suspended solids (VSS) of the bulk suspension, and membrane permeate were measured by Standard Method [45]. The SCOD concentration was measured after filtering the sample through a $0.45 \mu \mathrm{m}$ pore size using cellulose nitrate membrane filter (Whatman, CAT no.7184-004, Maidstone, UK). The VSS concentration was measured by using a $1.2 \mu \mathrm{m}$ glass filter (Whatman, GF/C, CAT no.1822-047, Maidstone, UK) according to the Standard Method (No.2540). The removal efficiency (Rc) was calculated according to the following equation.

$$
\mathrm{R}_{\mathrm{C}}=\left(1-\frac{\mathrm{CP}}{\mathrm{CF}}\right) \times 100 \%
$$

where $C_{F}$ is the concentration of the feed solution and $C_{p}$ is the concentration of the permeate solution, respectively. Composition of collected biogas was analyzed by using a Hewlett-Packard 6890 gas chromatograph (GC) equipped with a thermal conductivity detector (TCD) and a Hayesep D Packed Column 80/100 (Agilent Technology, Santa Clara, CA, USA); $0.5 \mathrm{~mL}$ of gas from Tedlar bag was injected into the GC-TCD by using the $1 \mathrm{~mL}$ gas-tight syringe (Hamilton, Reno, NV, USA). The methane production was calculated with a collected biogas volume and methane composition [4]. The surface of each media was observed by using a SEM (SU 8010, Hitachi Ltd., Tokyo, Japan) after platinum coating. The soluble extracellular polymeric substance (EPS) concentration of the bulk suspension was measured by a phenol-sulfuric acid colorimetric method [46]. Here, polysaccharides are assumed to be the major contributor to EPS and hydrolyzed by sulfuric acid to react with phenol. A $50 \mathrm{~mL}$ of bulk suspension taken from the reactor was centrifuged at $3200 \mathrm{rpm}$ for $30 \mathrm{~min}$. A deposit of the sample separated with supernatant was then mixed with $2 \mathrm{~mL}$ of $5 \%$ phenol, after which $10 \mathrm{~mL}$ of $98 \%$ sulfuric acid was added for about a $10 \mathrm{~min}$ reaction period at ambient temperature. Following the reaction, a UV/visible spectrometer measured the absorbance at $490 \mathrm{~nm}$. The absorbance was compared against the calibration curve developed with glucose standard solution prepared in the same way.

\section{Results and Discussion}

\subsection{Effect of Fluidization of Combined Media on Membrane Fouling}

Figure 2 shows the change of TMP with the time during the entire operational period of the AFMBR system. During the initial $90 \mathrm{~d}$ of operation at $5.3 \mathrm{~L} /\left(\mathrm{m}^{2} \mathrm{~h}\right)$ of permeate flux, which corresponds to $8 \mathrm{~h}$ of HRT, the TMP value was maintained at about $0.1 \mathrm{bar}$. After that, an increase in permeate flux from 5.3 to $7.1 \mathrm{~L} /\left(\mathrm{m}^{2} \mathrm{~h}\right)$ accelerated membrane fouling, showing a rapid increase in TMP to 0.45 bar at $110 \mathrm{~d}$ of AFMBR operation. Membrane relaxation was then applied by performing combined media fluidization without producing a membrane permeate for 1 min every 9 min of filtration. After that, the TMP was decreased to the 0.25 bar gradually and then remained during the rest of the operational period. However, further reduction in the TMP value below the 0.25 bar was not observed under the periodic filtration/relaxation at $7.1 \mathrm{~L} /\left(\mathrm{m}^{2} \mathrm{~h}\right)$ of permeate flux. 


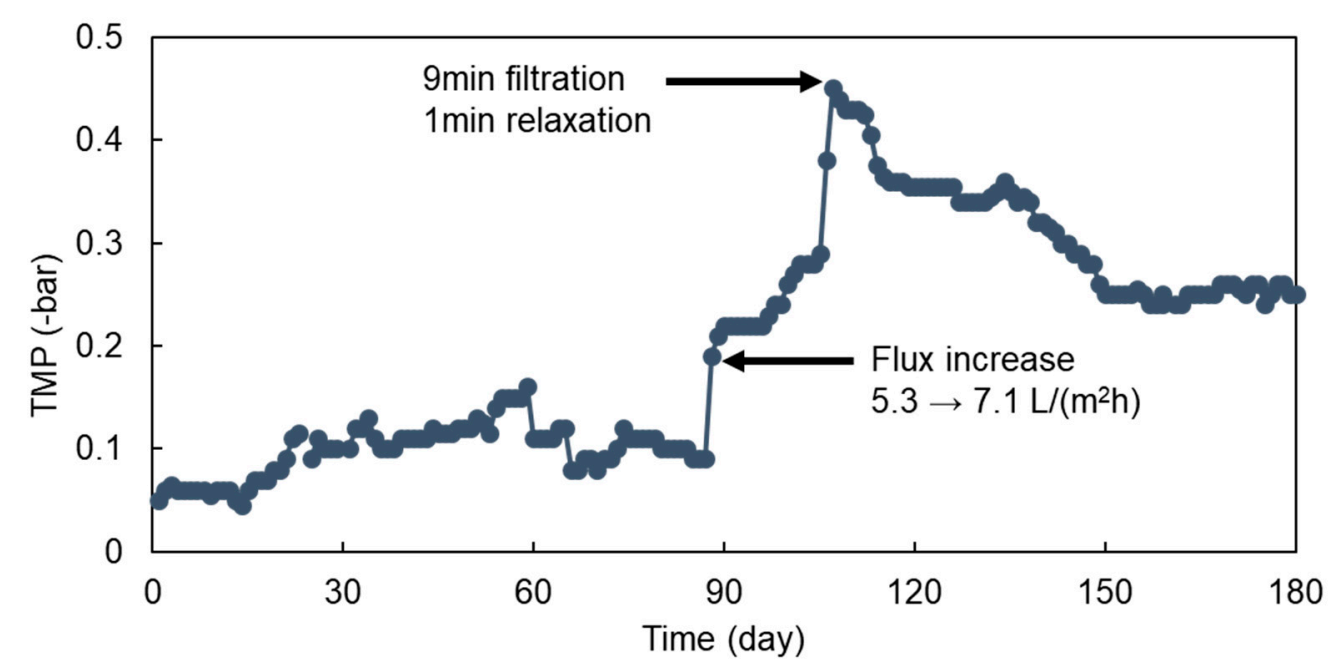

Figure 2. The TMP change of AFMBR with operation time.

The reduction in membrane fouling due to the scouring effect caused by the fluidization of GAC or plastic beads in AFMBR has been clearly shown in previous studies [22,24-26,38,47-51]. With a flat-tubular ceramic membrane, about $6 \mathrm{~L} / \mathrm{min}$ of recirculation flow rate was needed in AFMBR for the fluidization of GAC particles at $50 \%$ of the packing ratio. With media fluidization using the same membrane and reactor used previously, due to the lower specific gravity of ABS plastic beads than GAC (1.04 vs. 2.0), the recirculation flow rate needed to be reduced to $3 \mathrm{~L} / \mathrm{min}$ to avoid the overflow of the ABS beads through the recirculation line. That is, GAC particles could be fluidized along the bottom half of the membrane only, while the above half of the membrane was covered by ABS plastic beads (Figure 1). This fluidized stratification can be expected since the heavier particles require a higher upflow velocity around the particles to cover the whole surface area of the membrane [52]. In other words, the contact with lighter ABS plastic beads on the membrane could result in a less physical impact to reduce membrane fouling.

There is a relationship between the diameter of fluidized media and scouring intensity for the fluidized membrane reactor [53]. With bigger media, a higher recirculation flow rate was needed and this resulted in an improvement of particle motion, thus enhancing the cleaning efficiency on the membrane. In addition, more energy required to fluidize larger media leads to higher critical flux below which membrane fouling does not occur [53]. Reduction in the recirculation flow rate to avoid the overflow of ABS plastic beads through the reactor decreased a bulk upflow velocity along the membrane, and thus the fouling mitigation efficiency could be decreased.

\subsection{AFMBR Treatment Efficiency}

Figure 3 shows the variation of SCOD concentration and biogas proportion in permeate and its removal efficiency with time observed during $180 \mathrm{~d}$ of AFMBR operation. During the initial $30 \mathrm{~d}$ of operation, the SCOD removal efficiency was only 20 to $40 \%$ due to the period required for microbial acclimation and the small rejection efficiency of organic components by porous MF membrane as applied in this study. After $40 \mathrm{~d}$ of operation, the SCOD removal efficiency started to increase gradually and then was maintained at more than $90 \%$. During the initial 30 days of operation, no biogas was produced from the AFMBR, as shown in Figure 3b. At day 60, methane composed approximately $45 \%$ of the biogas and then increased to about $65 \%$ after day 80 . In addition, more than $90 \%$ of SCOD removal efficiency was achieved and stabilized at this operational period, suggesting that combined media fluidization consisting of GAC particles and ABS plastic beads did not provide any adverse impacts on the organic removal efficiency. The SCOD in bulk suspension and membrane permeate were almost similar, suggesting that most 
of the dissolved organic compounds should be removed by biodegradation rather than membrane filtration.
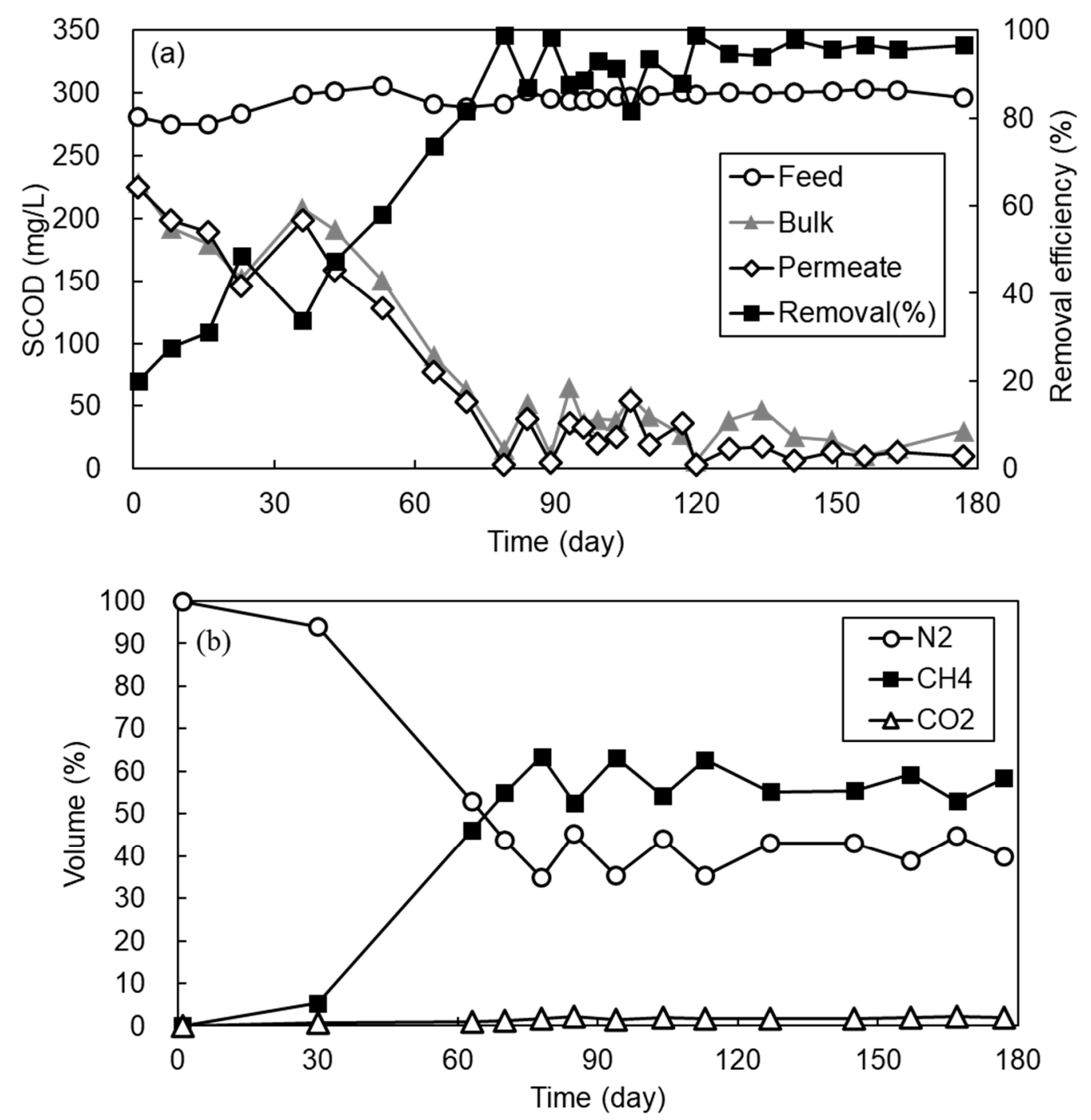

Figure 3. The variation of (a) SCOD and (b) biogas proportion for 180 days of AFMBR operation.

Table 3 shows the mean value of AFMBR performance for each operational period. As a set-point flux was $5.1 \mathrm{~L} /\left(\mathrm{m}^{2} \mathrm{~h}\right)$, the bulk VSS concentration was maintained as $370.8 \mathrm{mg} / \mathrm{L}$ on average under which the TMP value was only about 0.1 bar, probably due to the scouring action of combined media to the clean membrane. Furthermore, it was also found that a higher permeate flux resulted in a lower bulk VSS concentration. As the flux increased to $7.1 \mathrm{~L} /\left(\mathrm{m}^{2} \mathrm{~h}\right)$, the bulk VSS concentration reduced to $60 \mathrm{mg} / \mathrm{L}$, but the TMP jumped to 0.45 bar. A possible explanation for this is the transport of VSS present in reactor bulk toward the membrane surface could be more pronounced at a higher permeate flux, resulting in a higher fouling rate [21,54]. In other words, fluidizing plastic ABS beads and GAC particles together along the membrane surface was not very effective to reduce the fouling rate at $7.1 \mathrm{~L} /\left(\mathrm{m}^{2} \mathrm{~h}\right)$ of permeate flux as applied in this study. 
Table 3. The mean value of AFMBR performance during each operational period.

\begin{tabular}{lccc}
\hline \multicolumn{1}{c}{ Period } & $\mathbf{1}$ & $\mathbf{2}$ & $\mathbf{3}$ \\
\hline Day & $0 \sim 90$ & $91 \sim 110$ & $111 \sim 180$ \\
SCOD removal (\%) & $58.5 \pm 28.3$ & $89.3 \pm 4.4$ & $95.3 \pm 3.2$ \\
VSS in bulk (mg/L) & $370.8 \pm 100.0$ & $60.0 \pm 28.9$ & $211.7 \pm 92.5$ \\
Biogas $(\mathrm{L} / \mathrm{d})$ & $<1$ & 1 & 1 \\
Methane $\left(\mathrm{CH}_{4}, \%\right)$ & $37.1 \pm 27.3$ & $60.1 \pm 5.1$ & $56.3 \pm 2.5$ \\
\hline
\end{tabular}

After performing the membrane relaxation, bulk VSS concentration was increased significantly to $211.7 \mathrm{mg} / \mathrm{L}$, but TMP was reduced to 0.25 bar. This can support the fact that the media fluidization with GAC and ABS beads on membrane without conducting the permeation is effective to detach the foulant materials from the membrane. The VSS concentration in membrane permeate was near zero during the whole operational period, suggesting that the VSS should be rejected by the membrane almost completely. The EPS concentration in the bulk suspension measured at the end of the operation was $106.4 \mathrm{mg} / \mathrm{L}$. This value was slightly higher than that measured under the fluidization of single GAC [55], but lower than that measured by plastic bead alone as fluidized media in the AFMBR treating the same synthetic wastewater [24]. Although a direct comparison is difficult, our observation suggests that more biomass can be grown on the GAC particles, probably due to the higher surface area provided, thereby lowering the concentration of EPS in bulk suspension than when only the plastic bead is used. In the first $30 \mathrm{~d}$ of operation, no biogas was produced by the reactor. From the $60 \mathrm{~d}$ of operation, however, methane composition in the biogas produced by single AFMBR was increased gradually and approached about $63 \%$ at $80 \mathrm{~d}$ of operation. After reactor stabilization, the methane composition in biogas was maintained at a rate higher than 55\% regardless of the change in bulk VSS concentration under combined media fluidization.

\subsection{Microbial Analysis}

Figure 4 compares SEM images of GAC particles and ABS plastic beads taken from the AFMBR after $180 \mathrm{~d}$ of operation. As expected, the surface of bare GAC particles appears to be rougher and more porous than ABS plastic beads (Figure 4a,c). Thus, the biofilm may be grown on the GAC particles favorably, as shown in Figure $4 \mathrm{~b}$. Interestingly, there was considerable evidence that the ABS plastic beads provided a surface for the growth of microorganisms with a spherical morphology (Figure 4d). The hydrophobic surface of ABS beads may be involved in the adhesion of microorganisms [56-58]. However, more studies are needed to better understand interactive biofilm formation on polymeric materials such as ABS.

To further evaluate the microbial compositions in the combined media, we performed $16 \mathrm{~S}$ rRNA gene sequencing on bulk liquid, GAC and ABS beads. The samples were collected on day 168, during which the biogas production and methane composition had reached a steady state. Thus, the samples can represent matured microbial communities. Significant differences in the number of clean sequences between GAC (archaeal: 4788; bacterial: 49918) and ABS beads (archaeal: 1681; bacterial: 15033) were observed, while bulk (archaeal: 4817; bacterial: 57211) and GAC were comparable. Considering that the samples were processed using the same protocol, it is most likely that the low sequence count is attributed to the low DNA recovery from the ABS media. Although the SEM images suggested that microbes adhered to the surface of both media, the 16S rRNA gene data suggested that ABS harbored fewer microbes than GAC.

The Principal Coordinates Analysis (PCoA) visualized the difference in microbial composition among each sample (Figure 5). The separation among the three samples indicated that their microbial composition was distinctively different. Based on bacterial composition, the fluidized media were more similar than bulk liquid (Figure 5a), and this is mainly attributed to the lower abundance of Proteobacteria on both media ( 28 to $30 \%$ ) as compared to bulk liquid (50\%) (Table 4). Between GAC and ABS beads, compositional differences (2 
to $8 \%$ ) in the phyla Firmicutes, Patescibacteria, Planctomycetes and Spirochaetes further distinguished the two media. In terms of archaeal composition, on the contrary, GAC and bulk liquid shared a more similar profile (Figure 5b). In particular, the uncultured Ca. Methanofastidiosales was absent in both bulk liquid and GAC, but was present on ABS (4.4\%). These observations collectively suggest that biofilm and bulk communities in AFMBR are distinct from each other, corroborating with previous studies [59,60]. Collectively, biocarrier material is also a determining factor in how the microbial community is shaped.
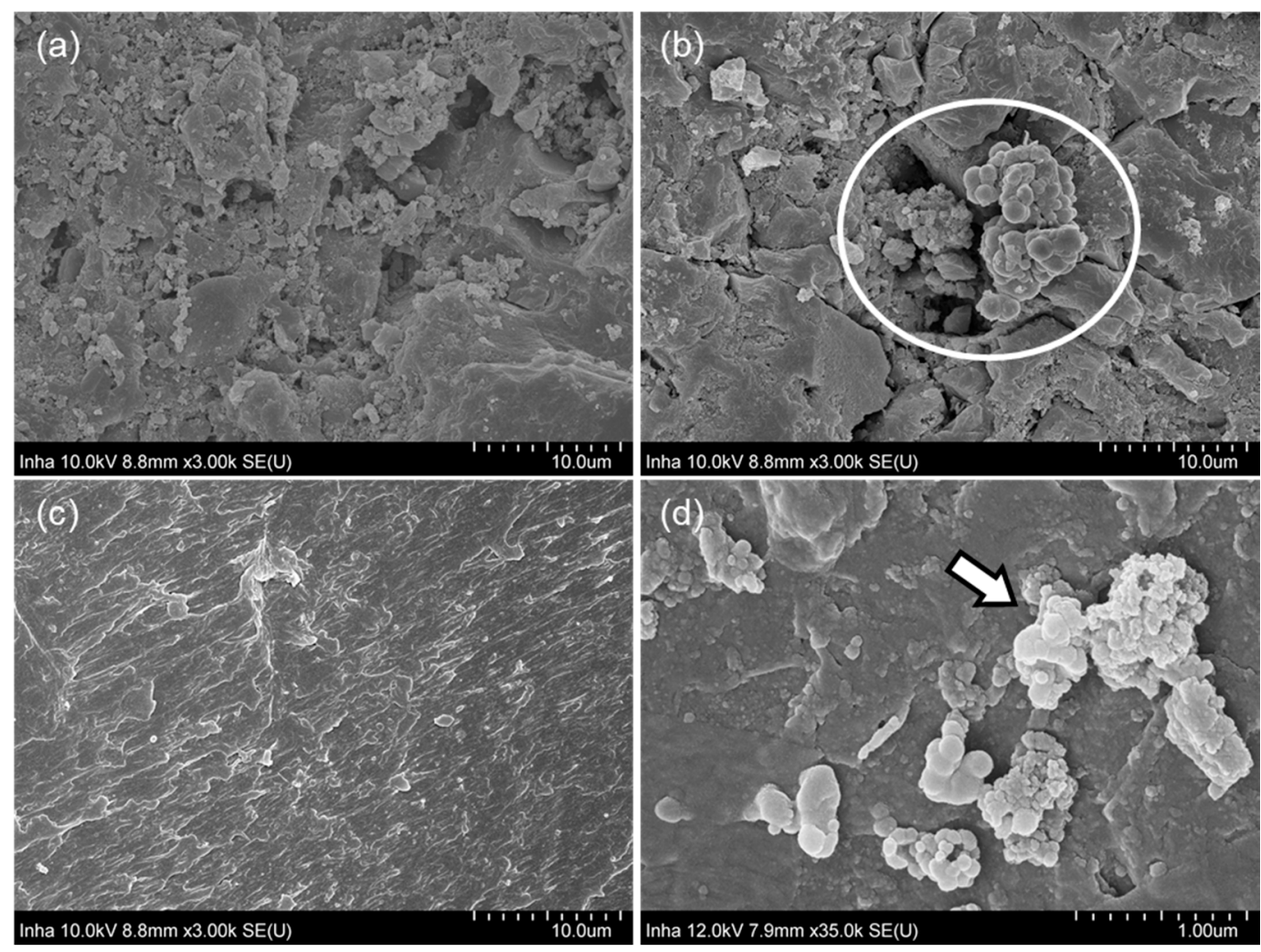

Figure 4. The SEM images of surface on (a) GAC, (b) used GAC, (c) ABS, and (d) used ABS media in AFMBR. (b,d) show some anaerobic microorganisms which adhered and were grown on the surface of each media.

Figure 6 illustrates the distribution of syntrophs, exoelectrogens, and methanogens to focus on how these substrates were consumed in different media. Based on taxonomic classification, the microbial metabolism on GAC and ABS beads were examined and compared. The syntrophs accounted for $9.29 \%$ of the bacterial population in the GAC sample, which mostly consisted of propionate-degrading Syntrophobacter (8.46\%). It also harbored exoelectrogens such as Desulfobulbus and Geobacter with relative abundances of $3.32 \%$ and $2.12 \%$, respectively. The sulfate-reducing Desulfobulbus reportedly utilizes propionate for growth and produces acetate under a sulfate-limiting environment, as is the case with our system [61]. This taxon was previously observed in an AFMBR system using polyvinylidene fluoride (PVDF) as a scouring agent and biocarrier [59], but its role in AD metabolism is still unclear. Aceticlastic Methanothrix (28.8\%) and an unclassified Methanomicrobia (38\%) were dominant methanogens in the GAC; the remaining methanogenic community consisted of hydrogenotrophic methanogens. Since acetate and propionate were used as carbon sources in the synthetic feed, Syntrophobacter was likely to convert propionate into acetate and hydrogen. While the hydrogenotrophic methanogens utilize hydrogen, acetate can then be utilized by Methanothrix for acetoclastic methanogenesis. Moreover, Geobacter can consume acetate and extracellularly release electrons that are used by Methanothrix via direct interspecies electron transfer (DIET) [62]. Under such circumstances, Methanothrix 
could utilize $\mathrm{CO}_{2}$ as the carbon source for methanogenesis, which would otherwise be impossible without its exoelectrongenic partner [60]. Although bulk liquid also contains Geobacter $(1.3 \%)$, the currently known mechanisms of DIET requires proximity to function and is unlikely to occur in the suspension of liquid [62].

(a) Bacterial communities

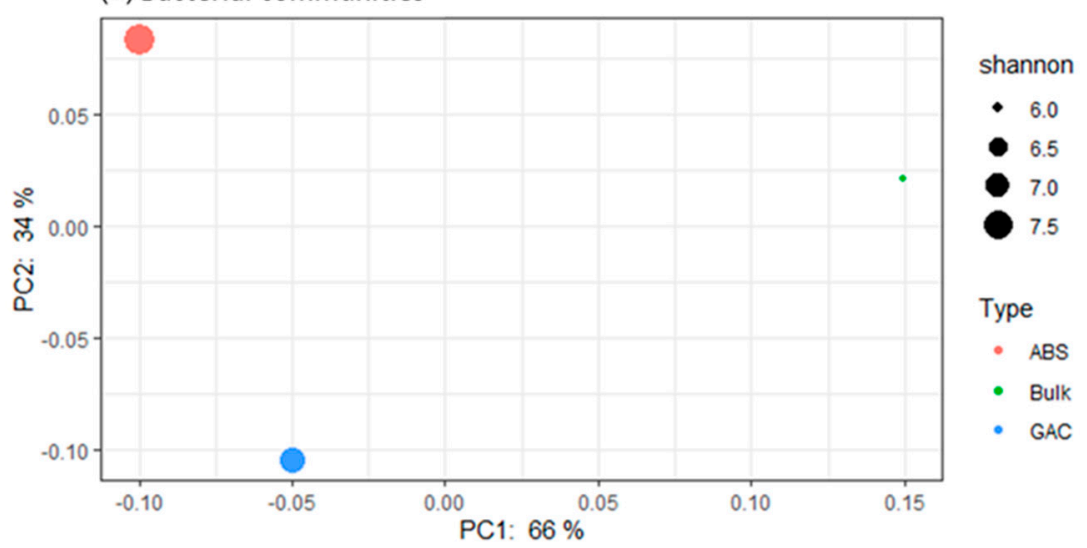

(b) Archaeal communities

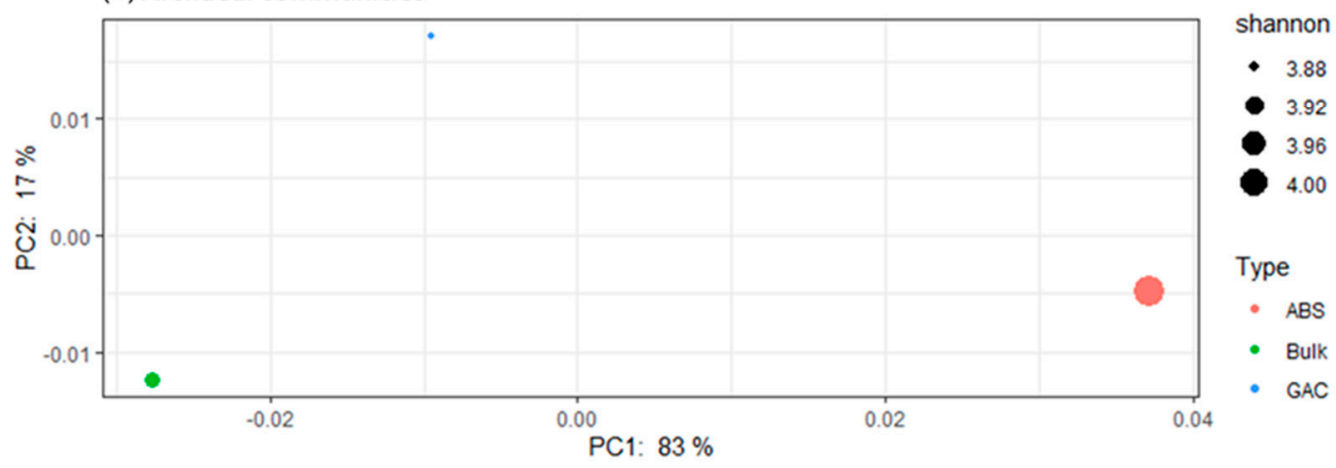

Figure 5. Principal coordinate analysis (PCoA) performed on microbial community structure dissimilarity. A weighted UniFrac distance metric was used to evaluate the compositional difference with the account of the relative abundance distribution. Samples were colored by their sample type. The size of the node was based on the value of the Shannon diversity index, which measures the richness and evenness of the microbial community. Panel (a) shows the result of the bacterial communities; panel (b) shows the results of the archaeal communities.

Table 4. A heat map of bacterial composition at the phylum level (relative abundance $>1 \%$ ).

\begin{tabular}{lccc}
\hline Phyla & Bulk & GAC & ABS \\
\hline Acidobacteria & 0.0081 & 0.0351 & 0.0459 \\
Bacteroidetes & 0.1964 & 0.1601 & 0.0987 \\
Caldiserica & 0.0032 & 0.0187 & 0.0124 \\
Chloroflexi & 0.0851 & 0.1701 & 0.1671 \\
Firmicutes & 0.0099 & 0.0162 & 0.0423 \\
Omnitrophicaeota & 0.0053 & 0.0345 & 0.0346 \\
Patescibacteria & 0.0352 & 0.1611 & 0.0768 \\
Planctomycetes & 0.0106 & 0.0197 & 0.0685 \\
Proteobacteria & 0.5090 & 0.3071 & 0.2854 \\
Spirochaetes & 0.0082 & 0.0090 & 0.0364 \\
Synergistetes & 0.0031 & 0.0183 & 0.0180 \\
\hline
\end{tabular}



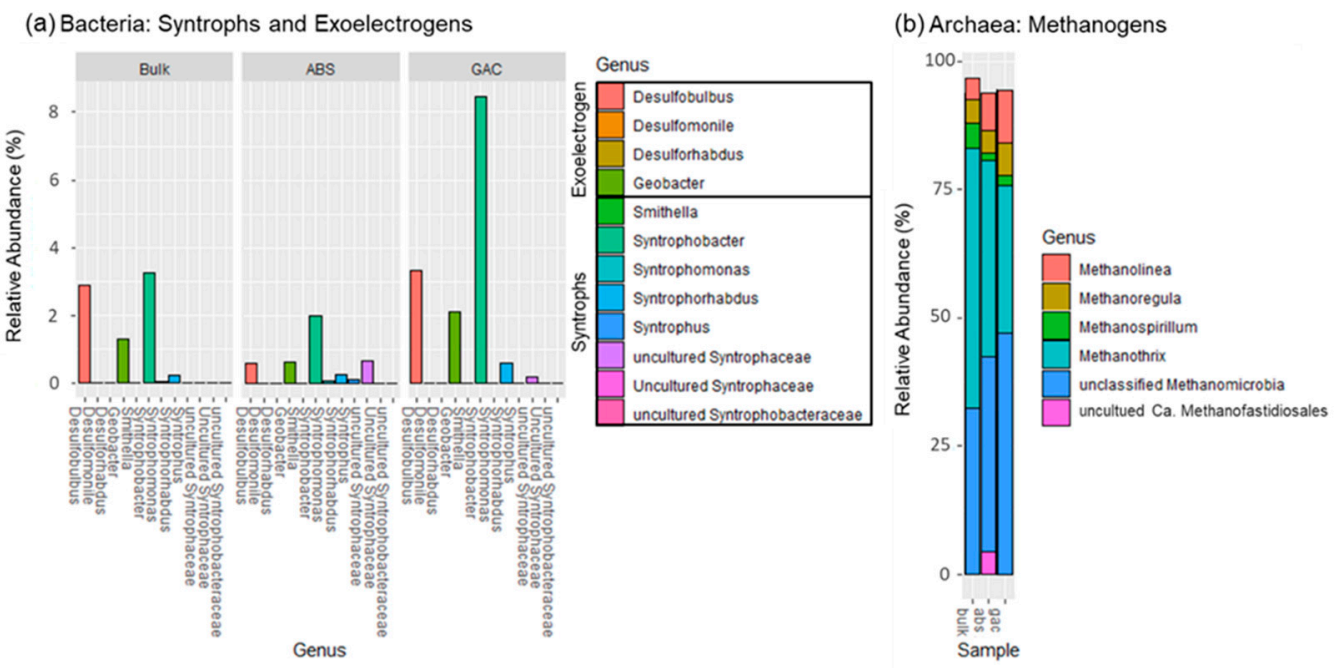

Figure 6. Microbial compositions illustrated in relative abundance at the genus level. Panel (a) shows the propionatedegrading syntrophic bacteria and exoelectrogens. Panel (b) shows the archaeal communities; non-methanogenic archaea are excluded.

In the ABS sample, the relative abundance of Syntrophobacter (2.01\%) and Geobacter $(0.65 \%)$ were lower than in the GAC, suggesting that the syntrophic synergy and occurrence of DIET were relatively limited. While ABS harbored a higher percentage of Methanothrix $(38.32 \%)$, it is most likely to produce methane via the acetoclastic pathway, as the Geobacter was in low relative abundance $(0.65 \%)$. Besides, Syntrophobacter only accounted for $2.01 \%$ of the bacterial population in ABS beads, and the total syntrophic population is about $3.15 \%$. Such synergy helps to maintain a thermodynamically favorable environment for the degradation of metabolites in the anaerobic digestion system [63]. While ABS beads could act as a biocarrier to facilitate the development of a syntrophic relationship between syntrophs and methanogens, the syntrophic synergy could be limited. It is plausible that compared to GAC, a more extended enrichment period is required for the development of a syntrophic population on ABS beads, although more studies would be needed to verify this.

\subsection{Energy Requirements}

The energy requirement of the pump for operating AFMBR was estimated using a power requirement equation as follows [55]:

$$
\mathrm{P}=\frac{\mathrm{Q} \gamma \mathrm{E}}{1000}
$$

where $\mathrm{P}$ is the power requirement of the pump $(\mathrm{kW}), \mathrm{Q}$ is the recirculation flow rate of bulk suspension $\left(\mathrm{m}^{3} / \mathrm{s}\right), \gamma$ is $9800 \mathrm{~N} / \mathrm{m}^{3}$, and E represents hydraulic pressure head loss for fluidization $\left(\mathrm{mH}_{2} \mathrm{O}\right)$.

Table 5 shows the calculation of the energy demand and energy production of AFMBR applied with dual media fluidization in this study. Assuming that the efficiency of the pump is $65 \%$, the total energy requirement is calculated as $2.03 \times 10^{-2} \mathrm{kWh} / \mathrm{m}^{3}$. When converting methane in the generated biogas to electrical energy with an efficiency of $33 \%$, it was calculated as $1.62 \times 10^{-1} \mathrm{kWh} / \mathrm{m}^{3}$ and the generated amount compared to the consumed amount was 7.97 times higher than the energy required to operate AFMBR. At $6 \mathrm{~L} / \mathrm{min}$ of recirculation flow rate, as only GAC particles were applied as fluidized media under $50 \%$ of the packing ratio, the total energy required at this condition was $3.09 \times 10^{-2} \mathrm{kWh} / \mathrm{m}^{3}$ [55]. As mentioned, combined use of GAC and ABS beads requires less energy than that needed by using a single GAC under the same total packing ratio $(50 \%)$ due to a lower recirculation flow rate required. Therefore, the combined use of both 
media provides a beneficial effect on reducing the operational costs of AFMBR while the fouling mitigation efficiency may be relatively low.

Table 5. Energy balance for electrical energy requirements and potential production with AFMBR.

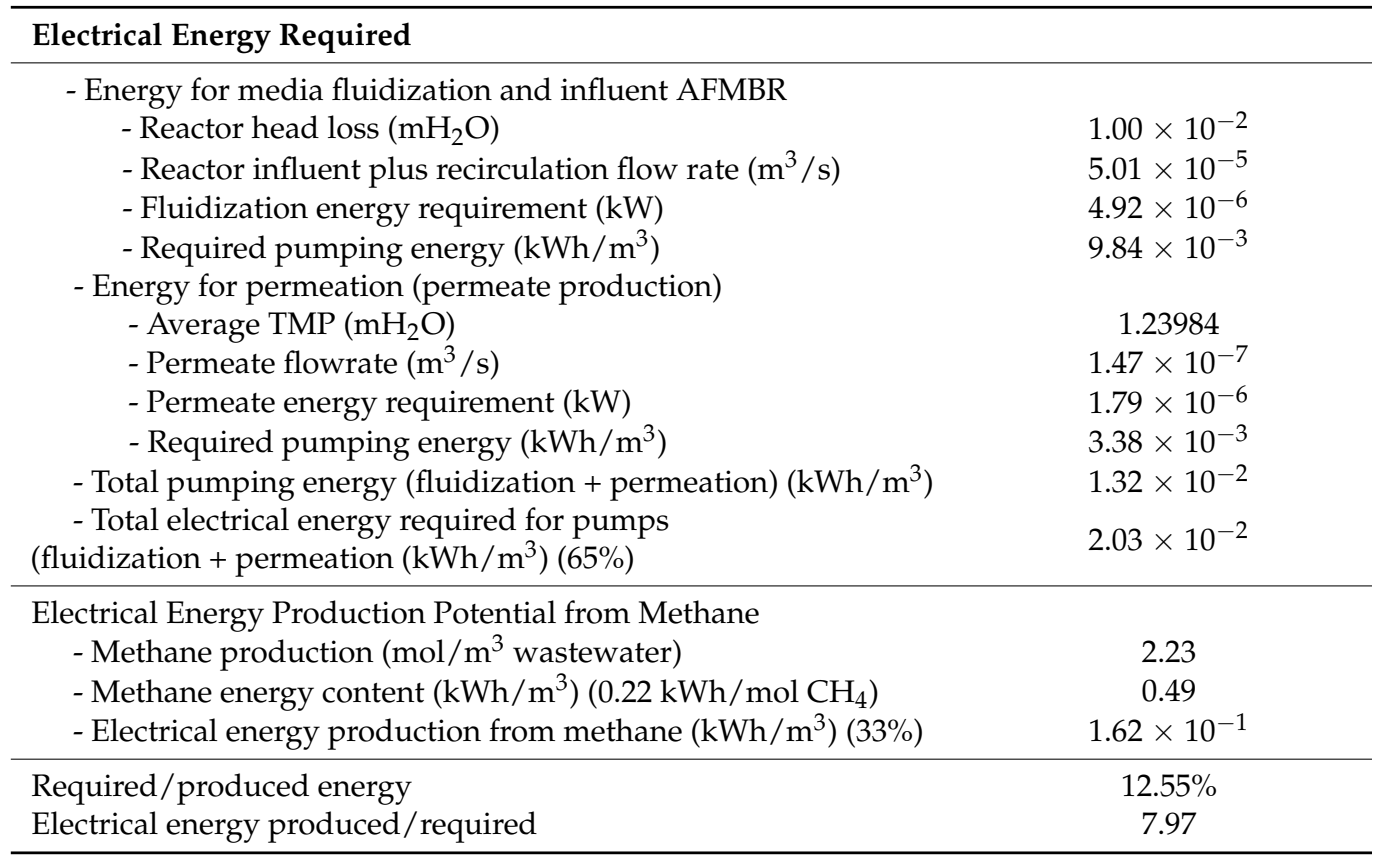

\section{Conclusions}

Combined media fluidization using GAC particles and ABS plastic beads in single AFMBR exhibited fouling mitigation effectively while limiting the TMP value to less than 0.2 bar at $6 \mathrm{~h}$ of HRT. Nevertheless, a high organic removal efficiency $(>90 \%)$ was achieved with the production of stable methane composition in the biogas as the two solid media were fluidized together. Microbes adhered to both media, but the microbial community was dependent upon the biocarrier material. The number of sequences was similar between GAC and bulk suspension, while fewer sequences were observed for ABS. Additionally, syntrophs and exoelectrogens population were more abundant on the GAC particles than the ABS beads. Therefore, it was more likely that DIET was utilized for methane production in GAC, while the microbes in ABS more heavily relied on traditional methanogenic pathways. The electrical energy required with dual media fluidization was only $0.02 \mathrm{kWh} / \mathrm{m}^{3}$, which was $87 \%$ lower than the energy produced by AFMBR system.

Author Contributions: Methodology, investigation, formal analysis and writing-original draft, D.K., M.K.; methodology, investigation, formal analysis and writing-original draft, T.Y.C.L.; Investigation, formal analysis, review and editing; G.-Y.A.T.; Investigation, formal analysis. Review and editing; P.-H.L.; Conceptualization, investigation, project administration, supervision, funding acquisition, review and editing; J.K. All authors have read and agreed to the published version of the manuscript.

Funding: This research was supported by the National Research Foundation of Korea (NRF) grant funded by the Korea government (MSIT)(2019R1A2C1087530).

Institutional Review Board Statement: Not applicable.

Informed Consent Statement: Not applicable.

Data Availability Statement: Not applicable.

Acknowledgments: This work was supported by the National Research Foundation of Korea (NRF) grant funded by the Korea government (MSIT) (2019R1A2C1087530).

Conflicts of Interest: The authors declare no conflict of interest. 


\section{References}

1. Kim, J.; Kim, K.; Ye, H.; Lee, E.; Shin, C.; McCarty, P.L.; Bae, J. Anaerobic Fluidized Bed Membrane Bioreactor for Wastewater Treatment. Environ. Sci. Technol. 2011, 45, 576-581. [CrossRef]

2. Gao, D.-W.; Hu, Q.; Yao, C.; Ren, N.-Q.; Wu, W.-M. Integrated anaerobic fluidized-bed membrane bioreactor for domestic wastewater treatment. Chem. Eng. J. 2014, 240, 362-368. [CrossRef]

3. Wu, B.; Wong, P.C.Y.; Fane, A.G. The potential roles of granular activated carbon in anaerobic fluidized membrane bioreactors: Effect on membrane fouling and membrane integrity. Desalination Water Treat. 2015, 53, 1450-1459. [CrossRef]

4. Lee, E.; Rout, P.R.; Shin, C.; Bae, J. Effects of sodium hypochlorite concentration on the methanogenic activity in an anaerobic fluidized membrane bioreactor. Sci. Total Environ. 2019, 678, 85-93. [CrossRef] [PubMed]

5. Düppenbecker, B.; Engelhart, M.; Cornel, P. Fouling mitigation in Anaerobic Membrane Bioreactor using fluidized glass beads: Evaluation fitness for purpose of ceramic membranes. J. Membr. Sci. 2017, 537, 69-82. [CrossRef]

6. Mutamim, N.S.A.; Noor, Z.Z.; Abu Hassan, M.A.; Olsson, G. Application of membrane bioreactor technology in treating high strength industrial wastewater: A performance review. Desalination 2012, 305, 1-11. [CrossRef]

7. Huang, L.; Lee, D.J. Membrane bioreactor: A mini review on recent R\&D works. Bioresour. Technol. 2015, 194, 383-388. [CrossRef]

8. Mustafa, N.; Elbeshbishy, E.; Nakhla, G.; Zhu, J. Anaerobic digestion of municipal wastewater sludges using anaerobic fluidized bed bioreactor. Bioresour. Technol. 2014, 172, 461-466. [CrossRef]

9. Akram, A.; Stuckey, D.C. Flux and performance improvement in a submerged anaerobic membrane bioreactor (SAMBR) using powdered activated carbon (PAC). Process Biochem. 2008, 43, 93-102. [CrossRef]

10. Damayanti, A.; Ujang, Z.; Salim, M.R. The influenced of PAC, zeolite, and Moringa oleifera as biofouling reducer (BFR) on hybrid membrane bioreactor of palm oil mill effluent (POME). Bioresour. Technol. 2011, 102, 4341-4346. [CrossRef]

11. Aun Ng, C.; Sun, D.; Fane, A.G. Operation of Membrane Bioreactor with Powdered Activated Carbon Addition. Sep. Sci. Technol. 2006, 41, 1447-1466. [CrossRef]

12. Chen, W.-H.; Tsai, C.-Y.; Chen, S.-Y.; Sung, S.; Lin, J.-G. Treatment of campus domestic wastewater using ambient-temperature anaerobic fluidized membrane bioreactors with zeolites as carriers. Int. Biodeterior. Biodegrad. 2019, 136, 49-54. [CrossRef]

13. Fernandez, N.; Montalvo, S.; Guerrero, L.; Sanchez, E.; Cortes, I.; Travieso, L. Anaerobic fluidized bed reactor application to tropical fruit wine effluent. Water Sci. Technol. 2007, 56, 33-38. [CrossRef] [PubMed]

14. Mutamim, N.S.A.; Noor, Z.Z.; Hassan, M.A.A.; Yuniarto, A.; Olsson, G. Membrane bioreactor: Applications and limitations in treating high strength industrial wastewater. Chem. Eng. J. 2013, 225, 109-119. [CrossRef]

15. Shin, C.; McCarty, P.L.; Kim, J.; Bae, J. Pilot-scale temperate-climate treatment of domestic wastewater with a staged anaerobic fluidized membrane bioreactor (SAF-MBR). Bioresour. Technol. 2014, 159, 95-103. [CrossRef] [PubMed]

16. Yoo, R.; Kim, J.; McCarty, P.L.; Bae, J. Anaerobic treatment of municipal wastewater with a staged anaerobic fluidized membrane bioreactor (SAF-MBR) system. Bioresour. Technol. 2012, 120, 133-139. [CrossRef]

17. Bae, J.; Shin, C.; Lee, E.; Kim, J.; McCarty, P.L. Anaerobic treatment of low-strength wastewater: A comparison between single and staged anaerobic fluidized bed membrane bioreactors. Bioresour. Technol. 2014, 165, 75-80. [CrossRef]

18. Wang, J.; Cahyadi, A.; Wu, B.; Pee, W.; Fane, A.G.; Chew, J.W. The roles of particles in enhancing membrane filtration: A review. J. Membr. Sci. 2020, 595, 117570. [CrossRef]

19. Shao, S.; Cai, L.; Li, K.; Li, J.; Du, X.; Li, G.; Liang, H. Deposition of powdered activated carbon (PAC) on ultrafiltration (UF) membrane surface: Influencing factors and mechanisms. J. Membr. Sci. 2017, 530, 104-111. [CrossRef]

20. Ng, C.A.; Sun, D.; Zhang, J.; Wu, B.; Fane, A.G. Mechanisms of Fouling Control in Membrane Bioreactors by the Addition of Powdered Activated Carbon. Sep. Sci. Technol. 2010, 45, 873-889. [CrossRef]

21. Lee, S.; Lee, J.-W.; Kim, S.; Park, P.-K.; Kim, J.-H.; Lee, C.-H. Removal of $17 \beta$-estradiol by powdered activated carbonMicrofiltraion hybrid process: The effect of PAC deposition on membrane surface. J. Membr. Sci. 2009, 326, 84-91. [CrossRef]

22. Aslam, M.; McCarty, P.L.; Bae, J.; Kim, J. The effect of fluidized media characteristics on membrane fouling and energy consumption in anaerobic fluidized membrane bioreactors. Sep. Purif. Technol. 2014, 132, 10-15. [CrossRef]

23. Yargicoglu, E.N.; Sadasivam, B.Y.; Reddy, K.R.; Spokas, K. Physical and chemical characterization of waste wood derived biochars. Waste Manag. 2015, 36, 256-268. [CrossRef]

24. Charfi, A.; Park, E.; Aslam, M.; Kim, J. Particle-sparged anaerobic membrane bioreactor with fluidized polyethylene terephthalate beads for domestic wastewater treatment: Modelling approach and fouling control. Bioresour. Technol. 2018, 258, 263-269. [CrossRef] [PubMed]

25. Casas, M.E.; Chhetri, R.K.; Ooi, G.; Hansen, K.M.; Litty, K.; Christensson, M.; Kragelund, C.; Andersen, H.R.; Bester, K. Biodegradation of pharmaceuticals in hospital wastewater by staged Moving Bed Biofilm Reactors (MBBR). Water Res. 2015, 83, 293-302. [CrossRef] [PubMed]

26. Barwal, A.; Chaudhary, R. To study the performance of biocarriers in moving bed biofilm reactor (MBBR) technology and kinetics of biofilm for retrofitting the existing aerobic treatment systems: A review. Rev. Environ. Sci. Biotechnol. 2014, 13, 285-299. [CrossRef]

27. Balart, R.; Lopez, J.; García, D.; Salvador, M.D. Recycling of ABS and PC from electrical and electronic waste. Effect of miscibility and previous degradation on final performance of industrial blends. Eur. Polym. J. 2005, 41, 2150-2160. [CrossRef]

28. Yang, S.; Castilleja, J.R.; Barrera, E.; Lozano, K. Thermal analysis of an acrylonitrile-butadiene-styrene/SWNT composite. Polym. Degrad. Stab. 2004, 83, 383-388. [CrossRef] 
29. Meincke, O.; Kaempfer, D.; Weickmann, H.; Friedrich, C.; Vathauer, M.; Warth, H. Mechanical properties and electrical conductivity of carbon-nanotube filled polyamide-6 and its blends with acrylonitrile/butadiene/styrene. Polymer 2004, 45, 739-748. [CrossRef]

30. Thakur, S.; Verma, A.; Sharma, B.; Chaudhary, J.; Tamulevicius, S.; Thakur, V.K. Recent developments in recycling of polystyrene based plastics. Curr. Opin. Green Sustain. Chem. 2018, 13, 32-38. [CrossRef]

31. Peszynska, M.; Trykozko, A.; Iltis, G.; Schlueter, S.; Wildenschild, D. Biofilm growth in porous media: Experiments, computational modeling at the porescale, and upscaling. Adv. Water Resour. 2016, 95, 288-301. [CrossRef]

32. Kim, C.; Lee, C.; Kim, S.W.; Kim, C.S.; Kim, I.S. Performance Evaluation and Fouling Propensity of Forward Osmosis (FO) Membrane for Reuse of Spent Dialysate. Membranes 2020, 10, 438. [CrossRef] [PubMed]

33. Pirbazari, M.; Voice, T.C.; Weber, W.J. Evaluation of Biofilm Development on Various Natural and Synthetic Media. Hazard. Waste Hazard. Mater. 1990, 7, 239-250. [CrossRef]

34. Barua, S.; Dhar, B.R. Advances towards understanding and engineering direct interspecies electron transfer in anaerobic digestion. Bioresour. Technol. 2017, 244, 698-707. [CrossRef] [PubMed]

35. Desrousseaux, C.; Cueff, R.; Aumeran, C.; Garrait, G.; Mailhot-Jensen, B.; Traoré, O.; Sautou, V. Fabrication of AcrylonitrileButadiene-Styrene Nanostructures with Anodic Alumina Oxide Templates, Characterization and Biofilm Development Test for Staphylococcus epidermidis. PLoS ONE 2015, 10, e0135632. [CrossRef] [PubMed]

36. Junker, L.M. Effects of triclosan incorporation into ABS plastic on biofilm communities. J. Antimicrob. Chemother. 2004, 53, 989-996. [CrossRef] [PubMed]

37. Park, J.-H.; Kang, H.-J.; Park, K.-H.; Park, H.-D. Direct interspecies electron transfer via conductive materials: A perspective for anaerobic digestion applications. Bioresour. Technol. 2018, 254, 300-311. [CrossRef]

38. Kwon, D.; Chang, H.; Seo, H.; Kim, J. Fouling behavior and system performance in membrane bioreactor introduced by granular media as a mechanical cleaning effect on membranes. Desalination Water Treat. 2016, 57, 9018-9026. [CrossRef]

39. Vo, T.-K.-Q.; Lee, J.-J.; Kang, J.-S.; Park, S.; Kim, H.-S. Nitrogen Removal by Sulfur-Based Carriers in a Membrane Bioreactor (MBR). Membranes 2018, 8, 115. [CrossRef]

40. Bolyen, E.; Rideout, J.R.; Dillon, M.R.; Bokulich, N.A.; Abnet, C.C.; Al-Ghalith, G.A.; Alexander, H.; Alm, E.J.; Arumugam, M.; Asnicar, F.; et al. Reproducible, interactive, scalable and extensible microbiome data science using QIIME 2. Nat. Biotechnol. 2019, 37, 852-857. [CrossRef]

41. Callahan, B.J.; McMurdie, P.J.; Rosen, M.J.; Han, A.W.; Johnson, A.J.; Holmes, S.P. DADA2: High-resolution sample inference from Illumina amplicon data. Nat. Methods 2016, 13, 581-583. [CrossRef] [PubMed]

42. Raschka, S.; Patterson, J.; Nolet, C. Machine Learning in Python: Main Developments and Technology Trends in Data Science, Machine Learning, and Artificial Intelligence. Information 2020, 11, 193. [CrossRef]

43. Quast, C.; Pruesse, E.; Yilmaz, P.; Gerken, J.; Schweer, T.; Yarza, P.; Peplies, J.; Glockner, F.O. The SILVA ribosomal RNA gene database project: Improved data processing and web-based tools. Nucleic Acids Res. 2013, 41, D590-D596. [CrossRef]

44. McMurdie, P.J.; Holmes, S. phyloseq: An R package for reproducible interactive analysis and graphics of microbiome census data. PLoS ONE 2013, 8, e61217. [CrossRef] [PubMed]

45. Rice, E.W.; Baird, R.B. Standard Methods for the Examination of Water and Wastewater, 23rd ed.; American Water Works Association and Water Environment Federation: Washington, DC, USA, 2017; pp. 144-153.

46. DuBois, M.; Gilles, K.A.; Hamilton, J.K.; Rebers, P.A.; Smith, F. Colorimetric method for determination of sugars and related substances. Anal. Chem. 1956, 28, 350-356. [CrossRef]

47. Siembida, B.; Cornel, P.; Krause, S.; Zimmermann, B. Effect of mechanical cleaning with granular material on the permeability of submerged membranes in the MBR process. Water Res. 2010, 44, 4037-4046. [CrossRef]

48. Basu, O.D.; Huck, P.M. Impact of support media in an integrated biofilter-submerged membrane system. Water Res. 2005, 39, 4220-4228. [CrossRef]

49. Johir, M.A.H.; Aryal, R.; Vigneswaran, S.; Kandasamy, J.; Grasmick, A. Influence of supporting media in suspension on membrane fouling reduction in submerged membrane bioreactor (SMBR). J. Membr. Sci. 2011, 374, 121-128. [CrossRef]

50. Hu, A.Y.; Stuckey, D.C. Activated carbon addition to a submerged anaerobic membrane bioreactor: Effect on performance, transmembrane pressure, and flux. J. Environ. Eng. 2007, 133, 73-80. [CrossRef]

51. Dutta, K.; Lee, M.Y.; Lai, W.W.; Lee, C.H.; Lin, A.Y.; Lin, C.F.; Lin, J.G. Removal of pharmaceuticals and organic matter from municipal wastewater using two-stage anaerobic fluidized membrane bioreactor. Bioresour. Technol. 2014, 165, 42-49. [CrossRef]

52. Shin, C.; Kim, K.; McCarty, P.L.; Kim, J.; Bae, J. Development and application of a procedure for evaluating the long-term integrity of membranes for the anaerobic fluidized membrane bioreactor (AFMBR). Water Sci. Technol. 2016, 74, 457-465. [CrossRef] [PubMed]

53. Wang, J.; Wu, B.; Yang, S.; Liu, Y.; Fane, A.G.; Chew, J.W. Characterizing the scouring efficiency of Granular Activated Carbon (GAC) particles in membrane fouling mitigation via wavelet decomposition of accelerometer signals. J. Membr. Sci. 2016, 498, 105-115. [CrossRef]

54. Iorhemen, O.T.; Hamza, R.A.; Tay, J.H. Membrane Bioreactor (MBR) Technology for Wastewater Treatment and Reclamation: Membrane Fouling. Membranes 2016, 6, 33. [CrossRef]

55. Aslam, M.; McCarty, P.L.; Shin, C.; Bae, J.; Kim, J. Low energy single-staged anaerobic fluidized bed ceramic membrane bioreactor (AFCMBR) for wastewater treatment. Bioresour. Technol. 2017, 240, 33-41. [CrossRef] 
56. Kochkodan, V.; Tsarenko, S.; Potapchenko, N.; Kosinova, V.; Goncharuk, V. Adhesion of microorganisms to polymer membranes: A photobactericidal effect of surface treatment with TiO2. Desalination 2008, 220, 380-385. [CrossRef]

57. Ridgway, H.F.; Rigby, M.G.; Argo, D.G. Bacterial adhesion and fouling of reverse osmosis membranes. J. Am. Water Work. Assoc. 1985, 77, 97-106. [CrossRef]

58. Gallardo-Moreno, A.M.; González-Martín, M.L.; Bruque, J.M.; Pérez-Giraldo, C. The adhesion strength of Candida parapsilosis to glass and silicone as a function of hydrophobicity, roughness and cell morphology. Colloids Surf. Physicochem. Eng. Asp. 2004, 249, 99-103. [CrossRef]

59. Kim, M.; Lam, T.Y.C.; Tan, G.-Y.A.; Lee, P.-H.; Kim, J. Use of polymeric scouring agent as fluidized media in anaerobic fluidized bed membrane bioreactor for wastewater treatment: System performance and microbial community. J. Membr. Sci. 2020, 606, 118121. [CrossRef]

60. Yang, P.; Tan, G.A.; Aslam, M.; Kim, J.; Lee, P.H. Metatranscriptomic evidence for classical and RuBisCO-mediated CO2 reduction to methane facilitated by direct interspecies electron transfer in a methanogenic system. Sci Rep. 2019, 9, 4116. [CrossRef] [PubMed]

61. Pagani, I.; Lapidus, A.; Nolan, M.; Lucas, S.; Hammon, N.; Deshpande, S.; Cheng, J.F.; Chertkov, O.; Davenport, K.; Tapia, R.; et al. Complete genome sequence of Desulfobulbus propionicus type strain (1pr3). Stand. Genom. Sci. 2011, 4, 100-110. [CrossRef] [PubMed]

62. Lovley, D.R. Syntrophy Goes Electric: Direct Interspecies Electron Transfer. Annu. Rev. Microbiol. 2017, 71, 643-664. [CrossRef] [PubMed]

63. Sieber, J.R.; McInerney, M.J.; Gunsalus, R.P. Genomic insights into syntrophy: The paradigm for anaerobic metabolic cooperation. Annu. Rev. Microbiol. 2012, 66, 429-452. [CrossRef] [PubMed] 